\title{
Non-targeted proteomics of acute respiratory distress syndrome: clinical and research applications
}

\author{
Xu-Peng Wen ${ }^{1}$, Yue-Zhong Zhang ${ }^{2}$ and Qi-Quan Wan ${ }^{1 *}$ (B)
}

\begin{abstract}
Acute respiratory distress syndrome (ARDS) is characterized by refractory hypoxemia caused by accumulation of pulmonary fluid with a high mortality rate, but the underlying mechanism is not yet fully understood, causing absent specific therapeutic drugs to treat with ARDS. In recent years, more and more studies have applied proteomics to ARDS. Non-targeted studies of proteomics in ARDS are just beginning and have the potential to identify novel drug targets and key pathways in this disease. This paper will provide a brief review of the recent advances in the application of non-targeted proteomics to ARDS.
\end{abstract}

Keywords: ARDS, Non-targeted proteomics, Clinical applications, Study designs

\section{Introduction}

Acute respiratory distress syndrome (ARDS) is a clinical syndrome caused by various pulmonary and extrapulmonary factors, characterized by refractory hypoxemia due to accumulation of pulmonary fluid [1]. There are more than 3 million patients with ARDS every year in the world. $10 \%$ of the patients in the intensive care unit (ICU) were admitted due to ARDS. The mortality rate of which was as high as $37.5 \%$ [2].

In recent years, with the development of molecular biology and bioinformatics, a variety of omics research methods have been applied to ARDS research, including genomics, transcriptomics, proteomics, and metabolomics [3], which have greatly accelerated the pace of ARDS research. Among them, as the main executor of life activities, proteomics plays an important role in the researches.

Proteome refers to all proteins expressed in a genome, a cell or tissue. This concept was first proposed by Marc

\footnotetext{
* Correspondence: 13548685542@163.com

'Transplantation Center, the Third Xiangya Hospital, Central South University, Changsha 410013, Hunan, China

Full list of author information is available at the end of the article
}

Wilkins in 1994 [4]. Proteomics can capture a complete set of expressed proteins in an organism, including protein isoforms and post-transcriptional modifications. By identifying the differentially expressed proteins or the whole set of proteins expressed in tissues or blood samples, we can analyze and understand the protein changes in the process of disease, find out the key targets, and study the corresponding genes and metabolites, to provide a starting point for exploring the pathogenesis, early diagnosis and treatment of the disease.

Although the application of proteomic technology to the study of the pathogenesis of ARDS has just started, its great potentials in deepening the understanding of protein expression patterns, discovering new injury mediators, and developing new therapeutic drugs have emerged [5]. In this paper, we will review the proteomics of ARDS reported in recent years, which is summarized as follows.

\section{Acute respiratory distress syndrome (ARDS)}

ARDS is a clinical syndrome characterized by high permeability pulmonary edema, which results in diffuse alveolar damage and often multiple organ failure $[6,7]$. 
The mortality of ARDS has declined considerably due to the advance in mechanical ventilation settings but still stays as high as $35-46 \%$. Such high mortality of ARDS patients means that no effective drug therapy is available for it yet. Here are several reasons for this phenomenon. First of all, ARDS is a comprehensive result of several pathways $[8,9]$, including endothelium injury and activation, epithelial injury, inflammation, coagulation, oxidative stress and metabolic dysfunction. Therefore, it is not effective enough to have treatment for a single protein or pathway. Secondly, since ARDS is a clinical syndrome resulting from different causes, such as pneumonia, bloodstream infections, lung contusion, shock and burn injury, are is divided into two aspects, direct and indirect causes [10], so it is difficult to cure ARDS targeting for one primary disease. Thirdly, The Berlin definition of ARDS addressed limitations of the American-European Consensus Conference definition, but poor reliability in applying some criteria by clinicians, and it was reported that such a degree is not useful to assess the severity and preview prognosis [2].

Some achievements have been made in the study of ARDS biomarkers, such as angiopoietin-2, surfactant proteins, glutathione, selectins, thrombomodulin, adenosine, Clara cell protein and many other biomarkers, which were reviewed before $[8,9,11-14]$. Whereas, several clinical trials failed since there were several pathways instead of a single one causing ARDS. Moreover, researchers majored in specified fields. Therefore, it means traditional methods to find biomarkers are too limited to be comprehensive. In consideration of such a phenomenon, non-targeted proteomic research was applied for ARDS.

\section{Non-targeted proteomics}

It is well known that the function of a cell is mainly determined by proteins rather than genes. Between a gene and its corresponding protein, great changes exist including the tissue-specific expression of genes, posttranscriptional modifications, post-translational modifications, protein-protein interactions and self-regulation of protein abundance. Therefore, proteomics is more practical and challenging than genomics. Non-targeted proteomics is a powerful domain to discover and assess proteins unbiasedly and quantitatively or semiquantitatively. Several reviews have introduced and summarized the detailed technologies and methods of nontargeted proteomics [11, 15-19], which would be omitted in this review.

\section{Development and comparisons of targeted versus non- targeted proteomics}

Strategies for performing proteomic experiments are classified as either 'targeted' or 'non-targeted. Targeted proteomics involves multiple analyses of known proteins and has been proved useful in assessing responses to the occurrence and progression of disease in the body. In contrast, non-targeted proteomics tries to detect as many different features as possible in a single analysis, and is combined with multivariate statistics to determine the biomarkers that distinguish cases and control groups. The application of the two groups of strategies is often confusing, so we summarize the advantages and disadvantages of the two groups of strategies in the following Table 1.

In theory, the weaknesses encountered in one proteomic approach are the respective strengths of the other one. Although the disadvantages of non-targeted proteomics determine that we cannot screen target proteins for absolute quantitative and qualitative research and analysis, which may be caused by different types of diseases and multiple internal and external factors, it cannot deny the important role of non-targeted proteomics in disease analysis. Over the past decade, non-targeted proteomics has offered a growing potential to identify new biomarkers compared to targeted proteomics.

\section{Non-targeted quantitative proteomic technologies based on mass spectrometry}

Since the concept of proteomics was put forward in 1994, quantitative proteomics has become the focus of proteomic research. It is to detect the difference in the quantity of total proteins expressed in normal and diseased tissues. Protein quantification technology in quantitative proteomics has also become an important way to discover biomarkers [20, 21]. In recent 10 years, with the rapid development of high-precision biological mass spectrometry (MS) and data processing technology, quantitative proteomic technologies have become the mainstream analysis method [22].

Non-targeted quantitative proteomic technology is for the undifferentiated analysis of all proteins in the samples, according to whether the proteins or peptides are labeled or not. It can be divided into label-free and stable isotop labeling. The advantages of this technique are low cost and simple sample preparation, and the quantitative error caused by sample pretreatment can be avoided by mixing different samples for mass spectrometry detection at the same time. Overall, the technical classification of non-targeted quantitative proteomics is shown in Fig. 1.

Notably, cell-free components, such as plasma and lung epithelial lining fluid have little DNA or RNA, but may have large numbers of proteins that are important markers of disease [16]. Up to now, proteomics has been widely used in studies of respiratory diseases, especially lung cancer, chronic obstructive pulmonary disease, asthma, pneumonia and idiopathic pulmonary fibrosis 
Table 1 Comparison of targeted and non-targeted proteomics

\begin{tabular}{ll}
\hline & Advantages \\
\hline Non- & a. Broad spectrum screening of disease-related proteins \\
targeted & b. Testing the samples and transitioning to targeted proteomics \\
proteomics & $\begin{array}{l}\text { c. To detect as many distinct features as possible in a single analysis and, } \\
\text { combined with multivariate statistics, identify biomarkers which distinguish } \\
\text { case from control groups } \\
\text { d. Allows larger scale studies of carefully phenotyped patients will identify } \\
\text { novel pathophysiology in the disease }\end{array}$
\end{tabular}

\author{
Disadvantages \\ a. The target protein cannot be well screened for \\ absolute quantitative and qualitative research and \\ analysis \\ b. Not entirely unbiased. The lack of absolute \\ quantification hampers benchmarking of 'normal' \\ protein levels and ultimately interlaboratory \\ comparison of results \\ c. False identification of proteins or bias/signal drift \\ introduced from matrix effects may also occur due to \\ a lack of standards
}

Targeted proteomics
a. To study different subtypes of the same disease type and draw a clinical reference map of biological targeted proteins, so as to guide clinical treatment
b. Excellent analytical precision
c. Unequivocal identification that can serve individually and together as biomarkers of both subphenotypes of disease and disease prognosis d. To reduce false positives which may lead to misinterpretation of an affected biological pathway

a. Limited coverage of the proteome which increases the risk of overlooking the proteomic response of interest.

b. When a narrower mass range was applied, these proteins were not observable in samples.

c. Limited resources and/or sample size and in the absence of prior knowledge on the protein of interest
[11]. Whereas few pieces of research focused on ARDS [12]. On the basis of previous proteomic studies of ARDS, advances in non-targeted proteomic techniques and methodologies have made it possible to use bronchoalveolar lavage fluid (BALF), lung tissue, blood, and exhaled air condensate for pulmonary proteomic studies [16].

\section{Non-targeted proteomics of ARDS}

From the first research of non-targeted proteomics in ARDS in 2004 [23], there were 16 studies in this field including 9 studies of human samples and 7 studies of rat or cell models. By analyzing the previous proteomic data, we can better understand the pathogenetic factors, signals, and events underlying ARDS. All these studies are summarized in Table 2.

\section{Samples in non-targeted proteomics of ARDS} Bronchoalveolar lavage fluid (BALF) proteome in ARDS

BALF is one of the most common sources of samples for the study of lung diseases. The studies of pathophysiological mechanism of ARDS revealed that alveolar epithelial cells and pulmonary capillary endothelial cells are damaged, and the increased pulmonary vascular permeability leads to exudative pulmonary edema [24, 27]. These pathophysiological changes may be explained by changes in the protein profile of alveolar lavage fluid. In 2004, Bowler et al. [23] first applied proteomic approaches to ARDS research. They used two-dimension (2-DE) technology and matrix-assisted laser desorption/ ionization time-of-flight mass spectrometry (MALDITOF-MS) technology and compared the BALF and plasma samples of ARDS patients with healthy people.

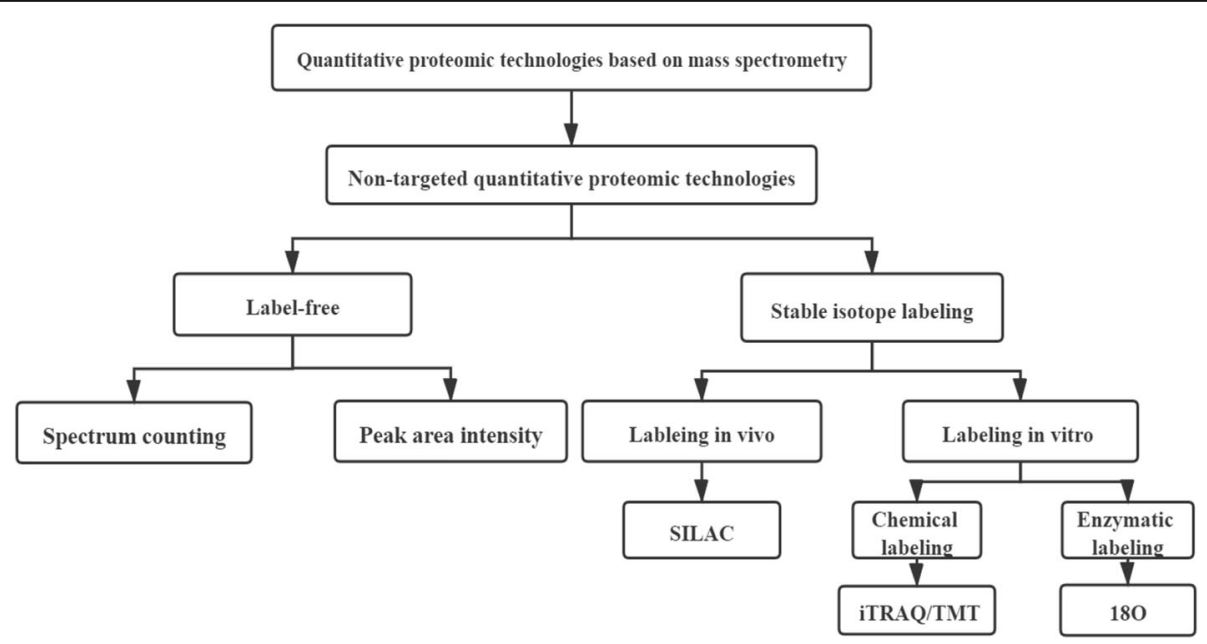

Fig. 1 Classification diagram of non-targeted quantitative proteomic techniques. This figure depicts the workflow of non-targeted quantitative proteomic techniques. SILAC: Stable isotope labeling by amino acids in cell culture; iTRAQ: Isobaric tags for relative and absolute quantitation; TMT: Tandem mass tags 
Table 2 Some representative non-targeted proteomics studies in ARDS

\begin{tabular}{|c|c|c|c|c|c|c|}
\hline Reference & Samples & Study objective & $\begin{array}{l}\text { Number of } \\
\text { subjects }\end{array}$ & $\begin{array}{l}\text { Number of identified } \\
\text { proteins; }\end{array}$ & $\begin{array}{l}\text { Top } 5 \text { up/down } \\
\text { regulated proteins }\end{array}$ & $\begin{array}{l}\text { Proteomics } \\
\text { methodology }\end{array}$ \\
\hline $\begin{array}{l}{[23]} \\
\text { Bowler RP } \\
2004\end{array}$ & $\begin{array}{l}\text { Plasma; } \\
\text { Edema fluid } \\
\text { in ARDS; } \\
\text { BALF }\end{array}$ & $\begin{array}{l}\text { To expatiate the protein } \\
\text { profiles }\end{array}$ & $\begin{array}{l}16 \text { ARDS; } \\
12 \text { healthy }\end{array}$ & $\begin{array}{l}300 \text { distinct protein spots; } \\
158 \text { proteins identified }\end{array}$ & $\begin{array}{l}\uparrow \text { : albumin, IgG, transferrin, } \\
\text { clusterin and hemoglobin } \\
\text { a2; } \\
\downarrow \text { : Surfactant protein A, a1- } \\
\text { antitrypsin, haptoglobin, } \\
\text { GST and transthyretin }\end{array}$ & $\begin{array}{l}\text { 2D-PAGE; } \\
\text { MALDI-TOF/ } \\
\text { MS }\end{array}$ \\
\hline $\begin{array}{l}\text { [24] De } \\
\text { Torre C } \\
2006\end{array}$ & BALF & $\begin{array}{l}\text { To assess pulmonary } \\
\text { inflammatory markers }\end{array}$ & $\begin{array}{l}11 \text { ARDS; } \\
33 \text { healthy } \\
\text { controls } \\
\text { challenged with } \\
\text { endotoxin }\end{array}$ & $\begin{array}{l}\text { Only differentially } \\
\text { expressed proteins } \\
\text { reported }\end{array}$ & $\begin{array}{l}\uparrow: \text { Apo A1, S100A8, } \\
\text { S100A9, AT III and } \\
\text { transthyretin }\end{array}$ & $\begin{array}{l}\text { SELDI-TOF/MS; } \\
\text { 2D-PAGE; } \\
\text { MALDI-TOF/ } \\
\text { MS }\end{array}$ \\
\hline $\begin{array}{l}{[25]} \\
\text { Schnapp } \\
\text { LM } 2006\end{array}$ & BALF & $\begin{array}{l}\text { To collect a more complete } \\
\text { protein profile }\end{array}$ & $\begin{array}{l}3 \text { ARDS; } \\
6 \text { healthy }\end{array}$ & $\begin{array}{l}226,291 \text { and } 659 \text { proteins } \\
\text { for the three patients } \\
\text { studied }\end{array}$ & $\begin{array}{l}\uparrow \text { : albumin, ceruloplasmin, } \\
\text { fibrinogen a chain, a1 } \\
\text { chymotrypsin, a2-HS- } \\
\text { glycoprotein and antitryp- } \\
\text { sin inhibitor }\end{array}$ & $\begin{array}{l}\text { 2D-HPLC; } \\
\text { Shotgun } \\
\text { Proteomics; } \\
\text { LC-MS/MS }\end{array}$ \\
\hline $\begin{array}{l}{[26]} \\
\text { Gessner C } \\
2008\end{array}$ & $\begin{array}{l}\text { Exhaled } \\
\text { breath }\end{array}$ & $\begin{array}{l}\text { To find biomarkers of ARDS } \\
\text { from } E B C\end{array}$ & $\begin{array}{l}24 \text { ARDS; } \\
10 \text { healthy; } \\
6 \text { pneumonia } \\
\text { (no ARDS) }\end{array}$ & 3 proteins & $\uparrow:$ cytokeratins 2, 9, and 10 & $\begin{array}{l}\text { 2D-PAGE; } \\
\text { MALDI-TOF/ } \\
\text { MS }\end{array}$ \\
\hline $\begin{array}{l}{[27]} \\
\text { Chang } \\
\text { DW } 2008\end{array}$ & BALF & $\begin{array}{l}\text { To examine changes of } \\
\text { protein expression by time }\end{array}$ & $\begin{array}{l}\text { ARDS on days } 1 \\
(n=7), 3(n=8) \\
\text { and } 7(n=5) \\
9 \text { healthy }\end{array}$ & $\begin{array}{l}991 \text { proteins spots seen. } \\
\text { Only } 80 \text { proteins spots } \\
\text { analyzed by MS which } \\
\text { represented } 37 \text { unique } \\
\text { proteins }\end{array}$ & $\begin{array}{l}\uparrow: \text { C3, S100A9, fibrinogen a } \\
\text { chain, a1-antitrypsin, Apo } \\
\text { A1 and hemopexin } \\
\text { precursor }\end{array}$ & $\begin{array}{l}\text { 2D-PAGE; } \\
\text { MALDI-TOF/ } \\
\text { MS }\end{array}$ \\
\hline $\begin{array}{l}\text { [28] Chen } \\
\text { X } 2013\end{array}$ & $\begin{array}{l}\text { Pooled } \\
\text { plasma }\end{array}$ & $\begin{array}{l}\text { To expound novel } \\
\text { biomarkers and identify the } \\
\text { potential ARDS treatment } \\
\text { targets }\end{array}$ & $\begin{array}{l}11 \text { ARDS (Direct } \\
\text { lung injury=6, } \\
\text { Indirect lung } \\
\text { injury }=5 \text { ); } \\
15 \text { healthy }\end{array}$ & 132 proteins & $\begin{array}{l}\uparrow: \text { SAA, isoform } 1 \text { of CRP, } \\
\text { a1-antichymotrypsin, } \\
\text { Leucine-rich a2- } \\
\text { glycoprotein and a1-AGP1 } \\
\downarrow \text { : complement factor H, } \\
\text { Apo A1, serotransferrin, } \\
\text { Apo C3 and Apo B100 }\end{array}$ & $\begin{array}{l}\text { MALDI TOF/ } \\
\text { TOF; iTRAQ; } \\
\text { LC-MS/MS }\end{array}$ \\
\hline $\begin{array}{l}{[29]} \\
\text { Nguyen } \\
\text { EV } 2013\end{array}$ & BALF & $\begin{array}{l}\text { To distinguish VAP in ARDS } \\
\text { patients }\end{array}$ & $\begin{array}{l}30 \text { ARDS: } 14 \text { VAP } \\
(+) \text { and } 16 \text { VAP } \\
(-) ; \\
5 \text { healthy }\end{array}$ & 76 proteins & $\begin{array}{l}\uparrow: \text { in VAP (+): S100A8, } \\
\text { elastase 2, lactotransferrin, } \\
\text { actinin } 1 \text { and calnexin; } \\
\text { In VAP (-): } \beta \text {-hemoglobin, } \\
\text { keratin 2, fibrinogen beta } \\
\text { chain, SERPINF1 and fibro- } \\
\text { nectin } 1\end{array}$ & $\begin{array}{l}\text { 2D-HPLC; } \\
\text { ESI-MS/MS }\end{array}$ \\
\hline $\begin{array}{l}\text { [30] Dong } \\
\text { H } 2013\end{array}$ & $\begin{array}{l}\text { Alveolar } \\
\text { macrophage }\end{array}$ & $\begin{array}{l}\text { Comparative analysis of } \\
\text { alveolar macrophage } \\
\text { proteome in patients with } \\
\text { ARDS }\end{array}$ & $\begin{array}{l}14 \text { ARDS (severe } \\
\text { infection): } \\
6 \text { Severe } \\
\text { pancreatitis, } \\
4 \text { acute } \\
\text { pyogenic } \\
\text { cholangitis, } \\
4 \text { acute ileus }\end{array}$ & 27 proteins & $\begin{array}{l}\uparrow: \text { (at the recovery phase): } \\
\text { GSTP1, PEX13, S100A8/A9 } \\
\text { and leukocyte elastase } \\
\text { inhibitor; } \\
\text { (at the exudative phase): } \\
\text { HSP27, annexin A8, } \\
\text { cathepsin B, napsin A and } \\
\text { galectin-3 }\end{array}$ & $\begin{array}{l}\text { 2D-PAGE; } \\
\text { MALDI-TOF/ } \\
\text { MS }\end{array}$ \\
\hline $\begin{array}{l}{[12]} \\
\text { Bhargava } \\
\text { M } 2014\end{array}$ & Pooled BALF & $\begin{array}{l}\text { To differentiate the } \\
\text { proteomic profiles in that } \\
\text { survivors from non-survivors }\end{array}$ & $\begin{array}{l}7 \text { early phase } \\
\text { ARDS survivors; } \\
8 \text { Early phase } \\
\text { ARDS non- } \\
\text { survivors; } \\
7 \text { late phase } \\
\text { ARDS survivors }\end{array}$ & $\begin{array}{l}724 \text { proteins identified; } \\
499 \text { proteins quantified }\end{array}$ & $\begin{array}{l}\uparrow: \text { : (in early survivors): AT III, } \\
\text { coagulation factor II/XII, } \\
\text { plasminogen, complement } \\
\text { C } 5 / C 1 \mathrm{r} \text {, and hemopexin } \\
\text { (in early non-survivors): } \\
\text { type I/IIIN collagen and } \\
\text { MMP } 9\end{array}$ & $\begin{array}{l}\text { iTRAQ; } \\
\text { 2D-HPLC; LC- } \\
\text { MS/MS }\end{array}$ \\
\hline $\begin{array}{l}{[31] \text { Liu D }} \\
2014\end{array}$ & lung tissue & $\begin{array}{l}\text { To obtain global protein } \\
\text { expression changes in ARDS } \\
\text { lung tissues and find new } \\
\text { therapeutic target of ARDS }\end{array}$ & $\begin{array}{l}\text { Pseudomonas } \\
\text { aeruginosa- } \\
\text { induced ALI rats }\end{array}$ & 18 proteins & $\begin{array}{l}\uparrow \text { : peroxiredoxin 1, } \\
\text { haptoglobin, GAPD, TCTP } \\
\text { and VDBG; } \\
\downarrow \text { : GSTA4, LGALS5, SPB1, } \\
\text { transthyretin and Rho- } \\
\text { associated protein kinase } 1\end{array}$ & $\begin{array}{l}\text { MALDI-TOF/ } \\
\text { MS }\end{array}$ \\
\hline $\begin{array}{l}{[32] \mathrm{Tao} J} \\
2016\end{array}$ & lung tissue & $\begin{array}{l}\text { To determine the } \\
\text { mechanism underlying JGT }\end{array}$ & $\begin{array}{l}3 \text { groups (Con, } \\
\text { Mod, and JGT-H) }\end{array}$ & 67 proteins & $\begin{array}{l}\uparrow: \text { Actn2, Ligp1, Serpina3n, } \\
\text { Mcm2, and Myl4; }\end{array}$ & $\begin{array}{l}\text { LC/MS; } \\
\text { iTRAQ }\end{array}$ \\
\hline
\end{tabular}


Table 2 Some representative non-targeted proteomics studies in ARDS (Continued)

\begin{tabular}{|c|c|c|c|c|c|c|}
\hline Reference & Samples & Study objective & $\begin{array}{l}\text { Number of } \\
\text { subjects }\end{array}$ & $\begin{array}{l}\text { Number of identified } \\
\text { proteins; }\end{array}$ & $\begin{array}{l}\text { Top } 5 \text { up/down } \\
\text { regulated proteins }\end{array}$ & $\begin{array}{l}\text { Proteomics } \\
\text { methodology }\end{array}$ \\
\hline & & treatment of ARDS & & & $\begin{array}{l}\text { \: Hbbt1, Hbbt2, Coq9, } \\
\text { Agrn and S1pr1 }\end{array}$ & LC Triple-TOF \\
\hline $\begin{array}{l}{[33] \mathrm{XuX}} \\
2017\end{array}$ & lung tissue & $\begin{array}{l}\text { To investigate the } \\
\text { relationship between } \\
\text { differentially expressed } \\
\text { proteins (DEPs) and the } \\
\text { pathogenesis of oleic acid } \\
(\mathrm{OA}) \text {-induced ALI in mice }\end{array}$ & $\begin{array}{l}\text { OA-treated ALI } \\
\text { rat model and } \\
\text { saline-treated } \\
\text { mice }\end{array}$ & $\begin{array}{l}849 \text { proteins were } \\
\text { differentially expressed } \\
\text { between the two groups, } \\
\text { including } 545 \text { upregulated } \\
\text { and } 304 \text { downregulated } \\
\text { proteins }\end{array}$ & $\begin{array}{l}\uparrow: \text { C1qA, ASCC3, Piwi-like } \\
\text { protein } 2 \text {, hemoglobin } \beta \\
\text { and Cxcl4; } \\
\downarrow \text { : Collagen Alpha-1(V) } \\
\text { Chain, GNAI1, chorion pro- } \\
\text { tein S18, VAMP3 and C-C } \\
\text { motif chemokine } 21 a\end{array}$ & iTRAQ \\
\hline $\begin{array}{l}{[34] \text { Tao Z }} \\
2017\end{array}$ & $\begin{array}{l}\text { macrophage } \\
\text { cells and } \\
\text { lung tissue }\end{array}$ & $\begin{array}{l}\text { To explore the protective } \\
\text { and therapeutic mechanisms } \\
\text { of SFJDC in a rat model }\end{array}$ & $\begin{array}{l}\text { LPS-induced ALI } \\
\text { rat models and } \\
\text { saline-treated } \\
\text { mice }\end{array}$ & $\begin{array}{l}4 \text { proteins in lung tissues; } \\
23 \text { overlapping candidate } \\
\text { proteins in AMs }\end{array}$ & $\begin{array}{l}\uparrow: \text { TNFAIP8, } \beta \text { - } \\
\text { hexosaminidase submit a, } \\
\text { 5-oxoprolinase, apoptosis- } \\
\text { inducing factor } 1 \text { and } \\
\text { histone-arginine methyl- } \\
\text { transferase CARM1 } \\
\text { \: MAPRC1, DNAJB11, } \\
\text { PRKCDBP, DNAJC5 and } \\
\text { MAP6 }\end{array}$ & $\begin{array}{l}\text { HPLC-MS / } \\
\text { MS, }\end{array}$ \\
\hline $\begin{array}{l}{[35] \mathrm{Ji} \mathrm{Z}} \\
2017\end{array}$ & serum of rat & $\begin{array}{l}\text { To find proteins may be } \\
\text { detected in the plasma of } \\
\text { patients at high risk of ARDS }\end{array}$ & $\begin{array}{l}\text { Rat model of } \\
\text { ARDS was } \\
\text { established by } \\
\text { cecal ligation } \\
\text { and puncture } \\
\text { surgery }\end{array}$ & $\begin{array}{l}38 \text { differentially expressed } \\
\text { immunogenic proteins }\end{array}$ & $\begin{array}{l}\uparrow: \text { RASL11A, LOC689092, } \\
\text { NUDT5, ENO1 and NEMF } \\
\text { \: CHDH, Ankrd24, TEC, } \\
\text { Phosphoglycerate kinase } 1 \\
\text { and EPC1 }\end{array}$ & $\begin{array}{l}\text { 2D-PAGE; } \\
\text { MALDI-TOF/ } \\
\text { TOF }\end{array}$ \\
\hline $\begin{array}{l}\text { [14] Janga } \\
\text { H } 2018\end{array}$ & $\begin{array}{l}\text { H441 } \\
\text { epithelial } \\
\text { cells and } \\
\text { endothelial } \\
\text { cells }\end{array}$ & $\begin{array}{l}\text { To analyse the site-specific } \\
\text { effects of LPS on the ACB } \\
\text { and reveal the effects on the } \\
\text { individual cell types and the } \\
\text { ACB as a functional unit }\end{array}$ & $\begin{array}{l}\text { H441 epithelial } \\
\text { cells and } \\
\text { endothelial cells }\end{array}$ & 5 proteins & $\begin{array}{l}\uparrow: \text { ICAM-1, VCAM-1, Angio- } \\
\text { poietin 2, Macrophage } \\
\text { colony-stimulating factor 1, } \\
\text { complement C1r and ca- } \\
\text { thepsin S }\end{array}$ & LS-MS \\
\hline $\begin{array}{l}\text { [36] Yue X } \\
2019\end{array}$ & BALF & $\begin{array}{l}\text { To explore the pathogenic } \\
\text { mechanisms of ARDS due to } \\
\text { direct and indirect } \\
\text { pulmonary insult }\end{array}$ & $\begin{array}{l}\text { control, } \\
\text { intratracheal (I.T., } \\
\text { direct) and } \\
\text { intraperitoneal } \\
\text { (I.P., indirect) } \\
\text { LPS-treated mice }\end{array}$ & $\begin{array}{l}1017 \text { proteins were } \\
\text { identified; } \\
\text { The two LPS groups } \\
\text { shared } 13 \text { up-regulated } \\
\text { and } 22 \text { down-regulated } \\
\text { proteins compared to the } \\
\text { control group }\end{array}$ & $\begin{array}{l}\uparrow: \text { Apcs, H2afz, Hba-a1, } \\
\text { Hist2h2aa2 and Hmgn2 } \\
\downarrow: \text { Anpep, Annexin A5, } \\
\text { AU021092, Cadm1 and } \\
\text { Cd200 }\end{array}$ & $\begin{array}{l}\text { Discovery- } \\
\text { Based } \\
\text { Quantitative } \\
\text { Shotgun } \\
\text { Proteomics }\end{array}$ \\
\hline
\end{tabular}

BALF Bronchoalveolar lavage fluid, DIGE Difference in-gel electrophoresis, iTRAQ Isobaric tags for relative and absolute quantitation, MALDI-TOF/MS Matrix-assisted laser desorption/ionization-time of flight/mass spectrometry, SELDI Surface-enhanced laser desorption ionization, 2D-HPLC Two-dimensional high-performance liquid chromatography, 2D-PAGE Two-dimensional polyacrylamide gel electrophoresis, LC-MS Liquid chromatograph-mass spectrometer, ESI-MS Electrospray ionization-mass spectrometer, VAP Ventilator associated pneumonia, SFJDC ShuFengJieDu Capsule, ACB Alveolar-capillary barrier, $\uparrow$ up-regulated proteins, $\downarrow$ downregulated proteins, GST Glutathione S-transferase, S100A8 calgranulin A, S100A9 calgranulin B, C3 Complement component C3, a1-AGP1 Alpha-1-acid glycoprotein 1, CRP C-reactive protein, SAA serum amyloid A protein, SERPINF1 serpin peptidase inhibitor, clade F, member 1, GSTP1 glutathione S-transferase pi-1. PEX13 Peroxisome biogenesis factor13, HSP27 Heat shock protein 27, MMP 9 matrix metallopeptidase 9, GAPD Glyceraldehyde-3-phosphate dehydrogenase, TCTP Translationally controlled tumor protein, VDBG Vitamin-D binding protein, GSTA4 Glutathione S-transferase alpha-4, LGALS5 Lectin, galactose binding, soluble 5, SBP1 Selenium-binding protein 1, C1qA Complement C1q subcomponent subunit A, ASCC3 Activating signal cointegrator 1 complex subunit 3, GNA11 Guanine nucleotide-binding protein $\mathrm{G}$ (i) subunit alpha-1, VAMP3 Vesicle-associated membrane protein 3, TNFAIP8 tumor necrosis factor a-induced protein 8, MAPRC1 membrane-associated progesterone receptor component 1, DNAJB11 DnaJ homolog subfamily B member 11, PRKCDBP Protein kinase $C$ delta-binding protein, DNAJC5 DnaJ homolog subfamily C member 5, MAP6 microtubule-associated protein 6, RASL11A RAS-like family 11 member A, LOC689092 Predicted: Nacetyllactosaminide $\beta-1,6-\mathrm{N}$-acetylglucosaminyl-transferase, NUDT5 Predicted: ADP-sugar pyrophosphatase isoform X1, ENO1 Eno1 protein, NEMF Nuclear export mediator factor, CHDH Choline dehydrogenase, Ankrd24 Ankyrin repeat domain 24, TEC TEC protein tyrosine kinase, EPC1 Predicted: Enhancer of polycomb homolog 1 isoform X2, ICAM-1 intercellular cell adhesion molecule-1, VCAM-1 vascular cell adhesion molecule-1, Apcs Serum amyloid P-component, H2afz Histone H2A.Z, Hba-a1 Hemoglobin subunit alpha, Hist2h2aa2 Histone H2A type 2-A, Hmgn2 Non-histone chromosomal protein HMG-17, Anpep Aminopeptidase N, AU021092 UPF0764 protein C16orf89 homolog, Cadm1 Cell adhesion molecule 1, Cd200 OX-2 membrane glycoprotein

This study found that some proteins were modified in many ways during lung injury, and these proteins could be identified by proteomic strategies at the time, but not by microarray, enzyme-linked immunosorbent assay (ELISA) or immunoblotting test or other identification methods. This method not only confirmed the existence of multiple subtypes of a single gene product in different disease states, but also demonstrated the potential and advantages of proteomic analysis in ARDS research.

With the development of proteomic technology, many low-abundance proteins that cannot be identified by traditional technologies have been identified, and together with known proteins, ARDS proteomic database has been constructed. Schnapp et al. [25] used a shotgun proteomic approach (2D-HPLC-MS/MS) to analyze 
BALF proteomic profiles from three ARDS patients and compared them with 6 healthy people. They showed that proteins of biological significance, such as insulin-like growth factor binding protein-3 (IGFBP-3), which were not previously identified in the BALF of ARDS patients, were followed by the ELISA method. It was verified that IGFBP-3 was significantly higher in the early stage of ARDS patients than in the normal control group. The author believed that IGFBP-3 down-regulated the expression of insulin-like growth factor in patients with ARDS and leaded to fibroblast apoptosis. At the same time, compared with the traditional proteomics methods, the identified proteins increased by nearly 10 times, suggesting that the shotgun technique is more comprehensive and reliable in identifying the ARDS protein profile.

Moreover, with the assistance of proteomics research, it is also possible to dynamically observe the changes of BALF protein during ARDS. Chang et al. [27] used 2DEMALDI-TOF-MS technology to analyze BALF proteins of patients with ARDS on day 1, 3 and 7 after disease onset, and identified 37 proteins, most of which did not change significantly at three-time points, only a few proteins changed significantly, including annexin A3, surfactant protein A, actin, etc. The dynamic changes of BALF proteins not only reflect the repair of lung damage, but may also predict the prognosis of ARDS patients.

Furthermore, in another study [19], the authors divided ARDS patients into three groups: early survivors (1-7 days after the onset of ARDS), early non-survivors, and late survivors (8-35 days after the onset of ARDS), and to compare and analyze the BALF of three groups by isotope tags for relative and absolute quantification (iTRAQ). Not only the dynamic changes of lung protein expression in early and late ARDS were found, but also the difference in protein expression between ARDS survivors and non-survivors was found. These differential proteins reflect a coordinated compensation response to injury and stress in early survivors. Confirmed by ELISA, Clara cell secretory protein, Moesin, Matrix metalloproteinase 9 (MMP-9), Mucoprotein $5 \mathrm{AC}$ and other proteins have been proved to be significantly different between the survival group and the non-survival group, which can be used as a potential biomarker to evaluate the prognosis of ARDS patients.

\section{Serum or plasma samples proteome in ARDS}

Compared with BALF, serum or plasma samples are relatively easy to obtain, and also contain some proteins associated with ARDS that may not be present in BALF, which is important to fully understand the pathophysiological mechanisms of ARDS. However, at the same time, high abundance proteins in serum may hinder the study of low abundance proteins $[12,35]$.
Chen et al. [37] combined the proteomic profile of inflammatory mediators together, using microarray technology to perform serum analysis on the normal control group, the bacterial-infected pneumonia group, and the pneumonia-ARDS group at three-time points (the day of the hospital, the third day, and the seventh day). Comparative analysis revealed 13 specific biomarkers for ARDS candidates. These candidate markers were evaluated through a digital evaluation scoring system, and the results were significantly related to clinical informatics. This research suggested that although microarray technology does not belong to the scope of proteomics technology, its large-scale study of protein characteristics can be a good method for studying proteomics.

In summary, limited and preliminary serum or plasma proteomic studies on ARDS may provide novel biomarker candidates and new insights into the pathogenesis of ARDS.

\section{Lung tissues proteome in ARDS}

The rat/mouse model of ARDS induced by various factors is often used to study the lung proteomics of ARDS [31]. Although the protein expression of lung tissue is inevitably different between mice and humans, these results can still provide a very important reference for the study of human ARDS. Also, some studies used 2-DEbased proteomic technology to study the characteristics of the lung tissue protein profiles obtained from patients with chronic obstructive lung disease (COPD) [13, 38]. However, as far as we know, there is still a lack of proteomic studies focusing on the identification and quantification of lung tissue proteins obtained from patients with ARDS. This is mainly due to the difficulty in obtaining sufficient lung tissue in critically ill patients. This is crucial because, compared with plasma proteomics, lung-specific proteomics is more capable of finding reliable and valuable biomarkers for the diagnosis, prognosis, pathogenesis and treatment of ARDS.

\section{Lung-related cells proteome in ARDS}

Alveolar macrophage (AM), the main defense cell in the airway, plays an important role in the pathogenesis and evolution of ARDS due to its role in phagocytosis and antigen presentation. When activated, they can secrete various cytokines or inflammatory factors to cause cascade inflammation [39, 40]. Dong et al. [30] believed that in addition to initiating, amplifying, and maintaining inflammatory response during the ARDS exudation period, $\mathrm{AM}$ also played a role in relieving persistent inflammation and preventing further tissue damage during the recovery period. Proteomic analysis and comparison of AM showed that the expression of 10 proteins significantly increased during the exudation period, and 17 proteins were significantly expressed during the recovery 
period, indicating that these 27 proteins were significantly related to the exudation period and the recovery period, respectively. Further analysis revealed that these proteins mainly played a role in regulating inflammation, oxidative stress, apoptosis and metabolism, and they had the potential to become biomarkers for early diagnosis and prognosis assessment of ARDS.

In another study, Bhargava et al. [41] studied the role of alveolar type II epithelial cells (AT II) in restoring the normal structure of alveoli in the injured lung and used proteomics methods to test AT II cells during the injury and recovery period of hyperoxia-induced ALI rat model. It was found that 183 kinds of proteins changed significantly from the injury to recovery period. Based on these data, the author also established a new algorithm to identify the protein clusters that change during the damage and repair of AT II cells, which provided an important basis for further research on the molecular mechanism of lung injury repair.

\section{Exhaled breath proteome in ARDS}

Exhaled gas condensates (EBC) contain small amounts of proteins that leave the lungs through the production of aerosol droplets [26, 42]. EBC's protein model may be useful for monitoring acute and severe lung diseases, mainly for monitoring inflammatory lung diseases, such as asthma, COPD, interstitial lung disease and ARDS, especially monitoring the pressure during mechanical ventilation. Gessner et al. [26] demonstrated an increased frequency of cytokeratin detection in EBC samples from mechanically ventilated patients with ARDS. The increase of cytokeratin detection rate was associated with higher PIP and PEEP levels, more severe lung injury and longer ventilation time. Therefore, the identification of markers of tissue injury indicating mechanical response during mechanical ventilation may provide an opportunity for future ventilation patterns to respond to lung tissue.

\section{Study designs in non-targeted proteomics of ARDS} Concerning the direct (pulmonary) or indirect (extrapulmonary) insults. In pulmonary ARDS, direct injury mainly affects alveolar epithelium with local alveolar inflammatory reaction, while in extrapulmonary ARDS, indirect injury affects vascular endothelium through inflammatory mediators in blood flow, showing more serious endothelial damage [36]. The pathogenesis of ARDS caused by direct and indirect lung injury is not fully understood. In a study [28], 26 patients with ARDS were divided into two groups: direct lung injury and indirect lung injury based on the etiology. For the first time, iTRAQ and MALDI-TOF-MS were used to perform proteomic analysis on the serum of each group of patients, and a total of 16 identified protein expression differences (compared with the normal control group) were found, of which 11 proteins were identified in both groups, while the other 5 proteins were only identified in the direct lung injury group. Through bioinformatics analysis, it was found that these differential proteins were mainly involved in lipid metabolism/transportation, immune system processes and other biological processes, and the acute phase response was the most important signal pathway.

Concerning the ARDS model mediated by various factors. Liu et al. [31] analyzed the proteome of lung tissue of ALI rats induced by Pseudomonas aeruginosa for the first time, and found that the expression levels of 18 kinds of proteins changed twice or more compared with the normal control group, which mainly involved in biological processes such as energy metabolism, antioxidant, protein binding and signal transduction. Among them, human antioxidant protein-1 (PRDXl) is considered to be the promoter of the inflammatory mechanism of ARDS. Western blot was used to confirm that PRDXI played a key role in promoting the inflammatory response of ARDS. Xu et al. [33] carried out a proteomic analysis on lung tissue of ALI mice induced by oleic acid and saline-treated mice by iTRAQ technology. After verification by Western blot, proteins such as antithrombin III (AT III), 12-lipoxygenase and cytokine-2 detoxification were selected as candidate biomarkers of ALI mice induced by oleic acid. After that, siRNA interference was used to study the effect of AT III on the integrity of pulmonary endothelial cells. The results showed that the expression level of inflammatory factors increased and the increased permeability of endothelial cells after AT III gene was deleted, indicating that AT III played an important role in oleic acid-induced ALI mice. In another study, Sakaue et al. [43] established a mouse model of ALI secondary to the liver injury induced by ligation of common bile duct, and carried out proteomic analysis on lung tissue. The results showed that compared with the control group, the expression of serine protease inhibitor Bla (serpin Bla), Annexin A1 (anxal) and calcium-binding protein A9 (S100A9) were significantly increased in the experimental group. Subsequently, immunohistochemistry technology and quantitative Reverse Transcription-Polymerase Chain Reaction (RT-PCR) technology were used to study lung tissue and liver tissue of mouse. The results of immunohistochemistry showed that the above three proteins were highly expressed in the pulmonary blood vessels in the ALI mouse model, and the quantitative RT-PCR results showed that serpin Bla was up-regulated in the liver, and S100A9 and anxal were up-regulated in the lung. This study linked liver injury with lung injury, and identified three proteins that may be involved in the pathological process of liver injury leading to lung injury, 
providing new insights into the diagnosis and treatment of ARDS. Xu et al. [44] confirmed that HA330 resindirected blood adsorption could reduce pulmonary edema and inflammatory damage caused by Lipopolysaccharide (LPS) by removing inflammatory factors in ARDS pig model proteomic study. Besides, some studies [45] reported that hydrogen has a protective effect on sepsis-related ALI. In this study, 192 differentially expressed proteins were found to be related to the mechanism of hydrogen action in sepsis-related ALI mice model induced by cecal ligation and puncture. These results provide new insights into the prevention or treatment of sepsis-related ALI by hydrogen.

Concerning the different periods of ARDS. Some studies [30] took the alveolar macrophages of patients with sepsis ARDS as the research object, using proteomics methods to study and analyze them in the early course of ARDS (within 24 h of onset) and on the 5th day of onset (significant improvement). It was found that 17 proteins were significantly increased during the recovery phase, while the remaining 10 proteins were upregulated in the early stages of the disease. The abovementioned proteins play a role in regulating inflammation, cytoskeleton organization, oxidative stress, apoptosis and metabolism. They may be used as biomarkers for the early diagnosis and prognosis of ARDS patients [27].

Concerning the complications of ARDS. Ventilatorassociated pneumonia (VAP) is a common complication in patients with ARDS. Nguyen and colleagues [29] obtained BALF from 5 normal subjects and 30 patients with ARDS which included 14 patients with VAP (VAP $(+)$ ), and 16 patients without (VAP (-)).In the ARDS group, they identified 76 differentially expressed proteins between $\operatorname{HAP}(+)$ and $\operatorname{VAP}(-)$. The functional analysis of these proteins indicated that the pro-inflammatory pathway was activated during VAP. They identified and verified a limited proteomic feature that can distinguish $\mathrm{VAP}(+)$ from $\mathrm{VAP}(-)$ patients, which is composed of the following three proteins: S100A8, Lactoferrin (LTF) and Actin 1 (ACTN1).

Concerning severe acute respiratory syndrome coronavirus 2(SARS-CoV-2)-infected host cells. As ARDS caused by the new coronavirus SARS-CoV-2 is raging around the world, coronavirus disease 2019 (COVID-19) is highly contagious $[46,47]$. With the help of unbiased proteomic technology, the infected cells can be detected to reveal the biological pathways and potential drug targets related to virus pathogenesis. However, this technology relies on the cell model of virus transient infection and the related high sensitivity proteomic methods. In the recent study [48], the author's team successfully isolated the SARS -cov-2 virus from the human colon epithelial carcinoma cell line Caco-2, and established the cell model. On the omics method, the team has recently developed a proteomic method called mePROD (multiplexed enhanced protein dynamics), which is used to deal with protein samples with weak label signals due to short-term processing. This method is based on stable isotope labeling by amino acids in cell culture (SILAC) labeling technology, which will not affect the cell itself, so it can be used to analyze the virus infected cells without deviation and interference. In this paper, the author used mepro D technology to detect proteins at different time points after the virus infection, determined the biological process related to infection, and then carried out the detection of potential drugs. These drugs could inhibit the replication of SARS - cov-2 at the concentration of non-toxic to human cells, which might provide therapeutic strategies for the treatment of COVID - 19 .

\section{Limitations in current studies}

As mentioned above, up to now, the research of nontargeted proteomics is limited by many internal and external factors. For different biological pathways, ARDS is a syndrome caused by different pathophysiological disorders, which limits the value of a single biomarker specific to a biological pathway. Models of multiple biomarkers from different biological pathways may be needed to establish reliable biological standards for ARDS [8]. Also, intriguingly, non-targeting techniques in proteomics are becoming an important way to find biomarkers related to ARDS.

For proteomic technology, some proteome, including low abundance proteins, membrane and hydrophobic proteins, as well as proteins with high molecular weight or extremely low or high $\mathrm{pH}$, cannot be well separated by $2-\mathrm{DE}$ and therefore cannot be detected by subsequent mass spectrometry [49]. Although the coupling of LC and MS significantly improves the separation, identification and quantification of small or hydrophobic proteins, it is still impossible to detect proteins of relatively low levels in various biological mixtures, such as chemokines, cytokines, growth factors, intracellular signaling proteins or transcription factors [50].

For the collection time of samples, the early collection of reliable timing sample biobank in the development of ARDS may enhance the efforts to deduce the biological signals of ARDS;

For sample selection and sample size, ARDS has wide heterogeneity, and small sample size may lead to heterogeneous conclusions. Currently, most studies choose plasma, but plasma and lung tissue are quite different; However, BALF is not easy to obtain. Some studies have shown that edema fluid can be directly sampled in the early stage of ARDS [11]. What's more, with the improvement of proteomic assessment of exhalation [12], 
this may be an attractive option to enhance the temporal/longitudinal evaluation of future studies.

Furthermore, most studies have not classified etiology. Calfee's study [51] used large clinical samples to classify the subtypes of ARDS, including a simplified model of two biomarkers (IL-6 and soluble TNFR-1) and clinical variables of vasopressor use at baseline, which correctly classified phenotypes in both populations with an accuracy of $>90 \%$. This suggests that this phenotype may be evaluated as a target population in future clinical trials.

\section{Conclusions}

\section{Future preview and application of ARDS therapy}

At present, there is no specific drug treatment for ARDS. Neuromuscular blocker is only an auxiliary drug of lung protection ventilation strategy. Proteomic methods can not only study the whole set of proteins of ARDS, find out the key target as the cut-off point of drug treatment, but also verify the drugs that may be effective treatments for ARDS, and study the possible mechanism of their intervention in the treatment of ARDS [8, 52]. Some studies [53] carried out a proteomic analysis on lung tissue of rats with ALI induced by high tidal volume ventilation, and found that the activity of matrix metalloproteinase-9 in lung was decreased after doxycycline treatment. Therefore, the authors suggested that doxycycline may prevent or treat high tidal volume ventilation-induced ALI by inhibiting the activity of matrix metalloproteinase-9. Certain Chinese medicine preparations such as ShuFengJieDu Capsule [34] and JieGeng-Tang [32] have certain therapeutic effects on ARDS, but the mechanism is unknown. Proteomic research can explain the possible potential effects of drugs.

In summary, researchers use proteomics technology to study samples of BALF, serum or plasma, lung tissue, lung cells and others from ARDS patients or animal models, revealing the pathophysiological mechanism of ARDS, screening new candidate biomarkers, searching for therapeutic targets and developing new drugs. At present, although the application of proteomic technology in the pathogenesis of ARDS is just started, its great potential has been shown in deepening the understanding of protein expression patterns in ARDS, discovering new damage mediators and developing new therapeutic drugs. After the completion of the human genome project, human proteome has become the main human science project [54], and the establishment of a proteome database of a single disease will also be the trend of disease research in the future [13].

\section{Abbreviations}

ARDS: Acute respiratory distress syndrome; ALI: Acute lung injury; ICU: Intensive care unit; BALF: Bronchoalveolar lavage fluid; DIGE: Difference in-gel electrophoresis; iTRAQ: Isobaric tags for relative and absolute quantitation; MALDI-TOF/MS: Matrix-assisted laser desorption/ionization-time of flight/mass spectrometry; SELDI: Surface-enhanced laser desorption ionization; 2D-HPLC: Two-dimensional high-performance liquid chromatography; 2D-PAGE: Two-dimensional polyacrylamide gel electrophoresis; LCMS: Liquid chromatograph-mass spectrometer; ESI-MS: Electrospray ionization-mass spectrometer; VAP: Ventilator associated pneumonia; SFJDC: ShuFengJieDu Capsule; ACB: Alveolar-capillary barrier; ELISA: Enzymelinked immunosorbent assay; IGFBP-3: Insulin-like growth factor binding protein-3; IGF: Insulin-like growth factor; MMP-9: Matrix metalloproteinase 9; AM: Alveolar macrophage; AT II: Alveolar type II epithelial cells; EBC: Exhaled gas condensates; PRDX 1: Human antioxidant protein-1; AT III: Antithrombin III; PT-PCR: Reverse Transcription-Polymerase Chain Reaction;

LPS: Lipopolysaccharide; SARS-CoV-2: Severe acute respiratory syndrome coronavirus 2; COVID-19: Coronavirus disease 2019

\section{Acknowledgements}

Not applicable.

Authors' contributions

Xu-Peng Wen was responsible for integrating all the information and finished this review; Yue-Zhong Zhang was responsible for collecting relevant data; Supervisor Qi-quan Wan helped them with this review all the way along.

\section{Funding}

This work was support by the Science and Technology Department of Hunan Province, China (grant 2020JJ4851).

Availability of data and materials

Not applicable.

\section{Declarations}

Ethics approval and consent to participate

Not applicable.

Consent for publication

Not applicable.

Competing interests

The authors declare that they have no competing interests.

\section{Author details}

${ }^{1}$ Transplantation Center, the Third Xiangya Hospital, Central South University, Changsha 410013, Hunan, China. ${ }^{2}$ Clinical Medicine, Xiangya School of Medicine, Central South University, Changsha 410083, Hunan, China.

Received: 4 January 2021 Accepted: 11 March 2021

Published online: 20 March 2021

\section{References}

1. Griffiths MJD, Mcauley DF, Perkins GD, et al. Guidelines on the management of acute respiratory distress syndrome[J]. BMJ Open Respir Res. 2019;6(1): e000420. https://doi.org/10.1136/bmjresp-2019-000420.

2. Fan E, Brodie D, Slutsky AS. Acute respiratory distress syndrome: advances in diagnosis and treatment[J]. JAMA. 2018;319(7):698-710. https://doi.org/10.1 001/jama.2017.21907.

3. Kan M, Shumyatcher M, Himes BE. Using omics approaches to understand pulmonary diseases[J]. Respir Res. 2017;18(1):149. https://doi.org/10.1186/s12 931-017-0631-9.

4. Cordwell SJ, Wilkins MR, Cerpa-Poljak A, Gooley AA, Duncan M, Williams KL, Humphery-Smith I. Cross-species identification of proteins separated by two-dimensional gel electrophoresis using matrix-assisted laser desorption ionisation/time-of-flight mass spectrometry and amino acid composition[J]. Electrophoresis. 1995;16(3):438-43. https://doi.org/10.1002/elps.1150160171.

5. Lynn H, Sun X, Casanova N, Gonzales-Garay M, Bime C, Garcia JGN. Genomic and genetic approaches to deciphering acute respiratory distress syndrome risk and mortality[J]. Antioxid Redox Signal. 2019;31(14):1027-52. https://doi.org/10.1089/ars.2018.7701.

6. Thompson BT, Chambers RC, Liu KD. Acute respiratory distress syndrome[J]. N Engl J Med. 2017;377(6):562-72. https://doi.org/10.1056/NEJMra1608077. 
7. Sweeney RM, Mcauley DF. Acute respiratory distress syndrome[J]. Lancet 2016;388(10058):2416-30. https://doi.org/10.1016/S0140-6736(16)00578-X.

8. Levitt JE, Rogers AJ. Proteomic study of acute respiratory distress syndrome: current knowledge and implications for drug development[J]. Expert Rev Proteomics. 2016;13(5):457-69. https://doi.org/10.1586/14789450.2016.11724 81.

9. Janz DR, Ware LB. Biomarkers of ALI/ARDS: pathogenesis, discovery, and relevance to clinical trials[J]. Semin Respir Crit Care Med. 2013;34(4):537-48. https://doi.org/10.1055/s-0033-1351124.

10. Rocco PR, Zin WA. Pulmonary and extrapulmonary acute respiratory distress syndrome: are they different?[J]. Curr Opin Crit Care. 2005;11(1):10-7. https:// doi.org/10.1097/00075198-200502000-00003.

11. Norman KC, Moore BB, Arnold KB, O'Dwyer DN. Proteomics: clinical and research applications in respiratory diseases[J]. Respirology. 2018;23(11):9931003. https://doi.org/10.1111/resp.13383.

12. Bhargava $M$, Higgins $L$, Wendt $\mathrm{CH}$, Ingbar $\mathrm{DH}$. Application of clinical proteomics in acute respiratory distress syndrome[J]. Clin Transl Med. 2014; 3(1):34. https://doi.org/10.1186/s40169-014-0034-1.

13. Xu XF, Dai HP, Li YM, Xiao F, Wang C. Mass spectrometry-based proteomics in acute respiratory distress syndrome: a powerful modality for pulmonary precision medicine[J]. Chin Med J. 2016;129(19):2357-64. https://doi.org/1 0.4103/0366-6999.190669.

14. Janga H, Cassidy L, Wang F, Spengler D, Oestern-Fitschen S, Krause MF, Seekamp A, Tholey A, Fuchs S. Site-specific and endothelial-mediated dysfunction of the alveolar-capillary barrier in response to lipopolysaccharides[]]. J Cell Mol Med. 2018;22(2):982-98. https://doi.org/10.1111/jcmm.13421.

15. Aebersold R, Mann M. Mass spectrometry-based proteomics[J]. Nature. 2003; 422(6928):198-207. https://doi.org/10.1038/nature01511.

16. Bowler RP, Ellison MC, Reisdorph N. Proteomics in pulmonary medicine[J]. Chest. 2006;130(2):567-74. https://doi.org/10.1378/chest.130.2.567.

17. Lam E, Dos Santos CC. Advances in molecular acute lung injury/acute respiratory distress syndrome and ventilator-induced lung injury: the role of genomics, proteomics, bioinformatics and translational biology[J]. Curr Opin Crit Care. 2008;14(1):3-10. https://doi.org/10.1097/MCC.0b013e3282f42211.

18. Ong SE, Mann M. Mass spectrometry-based proteomics turns quantitative[J]. Nat Chem Biol. 2005;1(5):252-62. https://doi.org/10.1038/nchembio736.

19. Bhargava M, Becker TL, Viken KJ, Jagtap PD, Dey S, Steinbach MS, Wu B, Kumar V, Bitterman PB, Ingbar DH, Wendt CH. Proteomic profiles in acute respiratory distress syndrome differentiates survivors from non-survivors[J]. PLoS One. 2014;9(10):e109713. https://doi.org/10.1371/journal.pone.0109713.

20. Ting L, Rad R, Gygi SP, Haas W. MS3 eliminates ratio distortion in isobaric multiplexed quantitative proteomics[J]. Nat Methods. 2011;8(11):937-40. https://doi.org/10.1038/nmeth.1714

21. Egertson JD, Kuehn A, Merrihew GE, Bateman NW, MacLean BX, Ting YS, Canterbury JD, Marsh DM, Kellmann M, Zabrouskov V, Wu CC, MacCoss MJ. Multiplexed MS/MS for improved data-independent acquisition[J]. Nat Methods. 2013;10(8):744-6. https://doi.org/10.1038/nmeth.2528.

22. Chahrour O, Cobice D, Malone J. Stable isotope labelling methods in mass spectrometry-based quantitative proteomics[J]. J Pharm Biomed Anal. 2015; 113:2-20. https://doi.org/10.1016/j.jpba.2015.04.013

23. Bowler RP, Duda B, Chan ED, Enghild JJ, Ware LB, Matthay MA, Duncan MW. Proteomic analysis of pulmonary edema fluid and plasma in patients with acute lung injury[J]. Am J Physiol Lung Cell Mol Physiol. 2004;286(6):L1095104. https://doi.org/10.1152/ajplung.00304.2003.

24. De Torre C, Ying SX, Munson PJ, et al. Proteomic analysis of inflammatory biomarkers in bronchoalveolar lavage[J]. Proteomics. 2006;6(13):3949-57. https://doi.org/10.1002/pmic.200500693.

25. Schnapp LM, Donohoe S, Chen J, Sunde DA, Kelly PM, Ruzinski J, Martin T, Goodlett DR. Mining the acute respiratory distress syndrome proteome: identification of the insulin-like growth factor (IGF)/IGF-binding protein-3 pathway in acute lung injury[J]. Am J Pathol. 2006;169(1):86-95. https://doi. org/10.2353/ajpath.2006.050612.

26. Gessner C, Dihazi H, Brettschneider S, Hammerschmidt S, Kuhn H, Eschrich K, Keller T, Engelmann L, Sack U, Wirtz H. Presence of cytokeratins in exhaled breath condensate of mechanical ventilated patients[J]. Respir Med. 2008:102(2):299-306. https://doi.org/10.1016/j.rmed.2007.08.012.

27. Chang DW, Hayashi S, Gharib SA, Vaisar T, King ST, Tsuchiya M, Ruzinski JT, Park DR, Matute-Bello G, Wurfel MM, Bumgarner R, Heinecke JW, Martin TR. Proteomic and computational analysis of bronchoalveolar proteins during the course of the acute respiratory distress syndrome[J]. Am J Respir Crit Care Med. 2008;178(7):701-9. https://doi.org/10.1164/rccm.200712-18950C.
28. Chen X, Shan Q, Jiang L, Zhu B, Xi X. Quantitative proteomic analysis by iTRAQ for identification of candidate biomarkers in plasma from acute respiratory distress syndrome patients[]]. Biochem Biophys Res Commun. 2013:441(1):1-6. https://doi.org/10.1016/j.bbrc.2013.09.027.

29. Nguyen EV, Gharib SA, Palazzo SJ, Chow YH, Goodlett DR, Schnapp LM. Proteomic profiling of bronchoalveolar lavage fluid in critically ill patients with ventilator-associated pneumonia[J]. PLoS One. 2013;8(3):e58782. https://doi.org/10.1371/journal.pone.0058782.

30. Dong H, Li J, Lv Y, Zhou Y, Wang G, Hu S, He X, Yang P, Zhou Z, Xiang X, Wang CY. Comparative analysis of the alveolar macrophage proteome in ALI/ARDS patients between the exudative phase and recovery phase[J]. BMC Immunol. 2013;14(1):25. https://doi.org/10.1186/1471-2172-14-25.

31. Liu D, Mao P, Huang Y, Liu Y, Liu X, Pang X, Li Y. Proteomic analysis of lung tissue in a rat acute lung injury model: identification of PRDX 1 as a promoter of inflammation[J]. Mediat Inflamm. 2014;2014:469358-14. https:// doi.org/10.1155/2014/469358

32. Tao J, Nie Y, Hou Y, Ma X, Ding G, Gao J, Jiang M, Bai G. Chemomicsintegrated proteomics analysis of Jie-Geng-tang to ameliorate lipopolysaccharide-induced acute lung injury in mice[J]. Evid Based Complement Alternat Med. 2016;2016:7379146-12. https://doi.org/10.1155/2 016/7379146

33. Xu X, Zhu Q, Zhang R, Wang Y, Niu F, Wang W, Sun D, Wang A. ITRAQ-based proteomics analysis of acute lung injury induced by oleic acid in mice[J]. Cell Physiol Biochem. 2017;44(5):1949-64. https://doi.org/10.1159/000485885.

34. Tao Z, Meng X, Han YQ, Xue MM, Wu S, Wu P, Yuan Y, Zhu Q, Zhang TJ, Wong CCL. Therapeutic mechanistic studies of ShuFengJieDu capsule in an acute lung injury animal model using quantitative proteomics technology[J]. J Proteome Res. 2017;16(11):4009-19. https://doi.org/10.1 021/acs.jproteome.7b00409.

35. Ji Z, Liu H, Fang L, Yu Y, Zhou Z. Use of immunoproteomics to identify immunogenic proteins in a rat model of acute respiratory distress syndrome[J]. Mol Med Rep. 2017;16(5):7625-32. https://doi.org/10.3892/ mmr.2017.7557

36. Yue X, Guidry JJ. Differential Protein Expression Profiles of Bronchoalveolar Lavage Fluid Following Lipopolysaccharide-Induced Direct and Indirect Lung Injury in Mice[J]. Int J Mol Sci, 2019, 20(14). doi:https://doi.org/10.3390/ ijms20143401, 20, 14.

37. Chen C, Shi L, Li Y, Wang X, Yang S. Disease-specific dynamic biomarkers selected by integrating inflammatory mediators with clinical informatics in ARDS patients with severe pneumonia[J]. Cell Biol Toxicol. 2016;32(3):169_ 84. https://doi.org/10.1007/s10565-016-9322-4

38. Ohlmeier S, Vuolanto M, Toljamo T, Vuopala K, Salmenkivi K, Myllärniemi M, Kinnula VL. Proteomics of human lung tissue identifies surfactant protein a as a marker of chronic obstructive pulmonary disease[J]. J Proteome Res. 2008;7(12):5125-32. https://doi.org/10.1021/pr800423x.

39. Jin M, Opalek JM, Marsh CB, Wu HM. Proteome comparison of alveolar macrophages with monocytes reveals distinct protein characteristics[J]. Am J Respir Cell Mol Biol. 2004;31(3):322-9. https://doi.org/10.1165/rcmb.200400800C.

40. Wu HM, Jin M, Marsh CB. Toward functional proteomics of alveolar macrophages[J]. Am J Physiol Lung Cell Mol Physiol. 2005;288(4):L585-95. https://doi.org/10.1152/ajplung.00305.2004.

41. Bhargava M, Dey S, Becker T, Steinbach M, Wu B, Lee SM, Higgins LA, Kumar $V$, Bitterman PB, Ingbar DH, Wendt $\mathrm{CH}$. Protein expression profile of rat type two alveolar epithelial cells during hyperoxic stress and recovery[J]. Am J Physiol Lung Cell Mol Physiol. 2013;305(9):L604-14. https://doi.org/10.1152/a jplung.00079.2013.

42. Gianazza E, Allegra L, Bucchioni E, Eberini I, Puglisi L, Blasi F, Terzano C, Wait $\mathrm{R}$, Sirtori CR. Increased keratin content detected by proteomic analysis of exhaled breath condensate from healthy persons who smoke[J]. Am J Med. 2004;117(1):51-4. https://doi.org/10.1016/j.amjmed.2004.01.022.

43. Sakaue T, Shikata F, Utsunomiya K, Fukae S, Kurata M, Nakaoka H, Okazaki M, Kawanishi Y, Kojima A, Higashiyama S, Izutani H. Proteomics-based analysis of lung injury-induced proteins in a mouse model of common bile duct ligation[J]. Surgery. 2017;161(6):1525-35. https://doi.org/10.1016/j.surg.201 6.12 .017

44. Xu X, Jia C, Luo S, Li Y, Xiao F, Dai H, Wang C. Effect of HA330 resin-directed hemoadsorption on a porcine acute respiratory distress syndrome model[J]. Ann Intensive Care. 2017;7(1):84. https://doi.org/10.1186/s13613-017-0287-0.

45. Bian Y, Qin C, Xin Y, Yu Y, Chen H, Wang G, Xie K, Yu Y. Itraq-based quantitative proteomic analysis of lungs in murine Polymicrobial Sepsis with 
hydrogen gas treatment[]]. Shock. 2018;49(2):187-95. https://doi.org/10.1 097/SHK.0000000000000927.

46. Zhu N, Zhang D, Wang W, Li X, Yang B, Song J, Zhao X, Huang B, Shi W, Lu R, Niu P, Zhan F, Ma X, Wang D, Xu W, Wu G, Gao GF, Tan W, China Novel Coronavirus Investigating and Research Team. A novel coronavirus from patients with pneumonia in China, 2019[J]. N Engl J Med. 2020;382(8):72733. https://doi.org/10.1056/NEJMoa2001017.

47. Zhao S, Lin Q, Ran J, Musa SS, Yang G, Wang W, Lou Y, Gao D, Yang L, He $\mathrm{D}$, Wang MH. Preliminary estimation of the basic reproduction number of novel coronavirus (2019-nCoV) in China, from 2019 to 2020: A data-driven analysis in the early phase of the outbreak[J]. Int J Infect Dis. 2020;92:214-7. https://doi.org/10.1016/j.jiji.2020.01.050.

48. Bojkova D, Klann K, Koch B, Widera M, Krause D, Ciesek S, Cinatl J, Münch C. Proteomics of SARS-CoV-2-infected host cells reveals therapy targets[]]. Nature. 2020:583(7816):469-72. https://doi.org/10.1038/s41586-020-2332-7.

49. Barnouin K. Two-dimensional gel electrophoresis for analysis of protein complexes[]]. Methods Mol Biol. 2004;261:479-98. https://doi.org/10.1385/159259-762-9:479

50. Issaq HJ. The role of separation science in proteomics research[J]. Electrophoresis. 2001;22(17):3629-38. https://doi.org/10.1002/1522-2683 (200109)22:17<3629::AID-ELPS3629>3.0.CO;2-O.

51. Calfee CS, Delucchi K, Parsons PE, Thompson BT, Ware LB, Matthay MA, NHLBI ARDS Network. Subphenotypes in acute respiratory distress syndrome: latent class analysis of data from two randomised controlled trials[]]. Lancet Respir Med. 2014;2(8):611-20. https://doi.org/10.1016/s2213-2 600(14)70097-9.

52. Meyer NJ, Calfee CS. Novel translational approaches to the search for precision therapies for acute respiratory distress syndrome[J]. Lancet Respir Med. 2017;5(6):512-23. https://doi.org/10.1016/S2213-2600(17)30187-X.

53. Doroszko A, Hurst TS, Polewicz D, Sawicka J, Fert-Bober J, Johnson DH, Sawicki G. Effects of MMP-9 inhibition by doxycycline on proteome of lungs in high tidal volume mechanical ventilation-induced acute lung injury[]]. Proteome Sci. 2010;8(1):3. https://doi.org/10.1186/1477-5956-8-3.

54. Yu H, Wang F, Lin L, Cao W, Liu Y, Qin L, Lu H, He F, Shen H, Yang P. Mapping and analyzing the human liver proteome: progress and potential[]]. Expert Rev Proteomics. 2016;13(9):833-43. https://doi.org/10.1 080/14789450.2016.1213132.

\section{Publisher's Note}

Springer Nature remains neutral with regard to jurisdictional claims in published maps and institutional affiliations.

Ready to submit your research? Choose BMC and benefit from:

- fast, convenient online submission

- thorough peer review by experienced researchers in your field

- rapid publication on acceptance

- support for research data, including large and complex data types

- gold Open Access which fosters wider collaboration and increased citations

- maximum visibility for your research: over $100 \mathrm{M}$ website views per year

At $\mathrm{BMC}$, research is always in progress.

Learn more biomedcentral.com/submissions 